\title{
A SELECTION INDEX FOR IMPROVING THE CARCASS TRAITS IN THE PANNON LARGE RABBIT BREED
}

\author{
Virág Ács ${ }^{1}$, István Nagy¹, Tamás Donkó1,2 \\ ${ }^{1}$ Faculty of Agricultural and Environmental Sciences, Kaposvár University, Guba S. str. 40., H-7400 Kaposvár, \\ Hungary \\ 2 Medicopus Nonprofit Ltd., Research Department, Guba S. str. 40., H-7400 Kaposvár, Hungary \\ To link to this article: https://doi.org/10.11118/actaun201967051125 \\ Received: 8. 7. 2019, Accepted: 9. 8. 2019
}

To cite this article: ÁCS VIRÁG, NAGY ISTVÁN, DONKÓ TAMÁS. 2019. A Selection Index for Improving the Carcass Traits in the Pannon Large Rabbit Breed. Acta Universitatis Agriculturae et Silviculturae Mendelianae Brunensis, 67(5): 1125-1129.

\begin{abstract}
Loin muscle volume and hind leg muscle volume measured by computer tomography are economically valuable traits in rabbit breeding. Hence, genetic parameters were calculated to these new selection criteria, and a two-trait selection index was created in order to modify the current selection process of the Pannon large rabbit breed. The evaluated animals $(\mathrm{n}=312)$ were randomly selected from 2014 and 2018, and the total number of animals in the pedigree file was 2758. Loin muscle volume (LMV) and hind leg muscle volume (HLV) were analyzed in a two-trait animal model. The estimated heritability for LMV was $h^{2}=0.4$ and $h^{2}=0.42$ for the HLV respectively. The selection index was created with desired gains by improving each trait in the selection criteria with one additive genetic standard deviation and the final index was Z transformed. Correlation coefficients between the index and the examined traits were high, 0.86 for LMV and 0.87 for HLV, thus this method could be announced into the breeding program.
\end{abstract}

Keywords: rabbit selection, computer tomography, selection index

\section{INTRODUCTION}

In breeding programs, paternal lines are usually selected to feed efficiency, growth rate or carcass traits considering rabbit breeds (Piles et al., 2000; Khalil and Al-Saef, 2008). The Pannon breeding program (Matics et al., 2014) was established in Kaposvár University including three rabbit breeds selected by different purposes since the late 1980s. The selection criteria differed from time-to time according to economic reasons and the consumer's demands. Pannon white was the first breed created from New Zealand white rabbits, followed by the maternal breed; Pannon Ka and the terminal breed Pannon Large.

Applying non-invasive techniques to shorten generation intervals and improve selection intensity are well-known and commonly used in animal breeding, by making progeny testing unnecessary (Jones et al., 2004; Gjerlaug-Enger et al., 2012). There were many aspirations previously, to find the best phenotypic correlation between carcass traits and CT based evaluations by Szendrő et al., (1992). The average surface of muscle longissimus dorsi between the $2^{\text {nd }}$ and $3^{\text {rd }}$, and $4^{\text {th }}$ and $5^{\text {th }}$ lumbar vertebrae (L-value) obtained the strongest correlation with the dressing out percentage for the Pannon white, $(r=0.53-0.65)$ but the technology did not allow to measure the volume of the whole muscle correctly back then. During the development of Pannon large in 2005, -as a paternal line- average daily gain (ADG) between 5 and 10 weeks of age became the first step of the selection process, and thigh muscle volume (TMV) was the second part. From the abattoir's point of view, 
the loin muscle (LM) represents another essential element of the valuable meat parts, and nowadays can be measured by automatic segmentation. In addition, for some specific product, the whole hind leg of the rabbit is used, so it is important, to recommend new traits in the breeding goal such as loin muscle volume (LMV) and hind leg muscle volume (HLV).

For combining multiple traits in the selection criteria, selection index method (Hazel, 1943) has the aspects to maximize genetic progress. To express the importance of the traits, selection index with desired gains can be interpreted, which was firstly described by Pesek and Baker (1969). These indices are good alternatives for breeders regarding the economic weights are changing as the market changes. Hence, the aim of the study was to put a desired gain selection index to the valuable meat parts of the Pannon Large rabbit breed.

\section{MATERIALS AND METHODS}

\section{Data Collection}

The analysis consisted of 312 randomly selected animals of Pannon Large rabbit breed from Kaposvár University, Hungary. Records were collected between 2014 and 2018, according to the changes of the scanning method (Donkó et al., 2016). In the first step of data collection, average daily gain (ADG) was measured, and animals with the best ADG were selected for the CT examination. During the evaluation three rabbits were fixed in a special plastic container without any anesthetics at 11 weeks of age, as in the standard selection program. The used acquisition parameters were: tube voltage $140 \mathrm{kV}$, X-ray radiation dose $90 \mathrm{mAs}$, spiral data collection mode with pitch 1 , field of view $500 \mathrm{~mm}$, slice thickness $2 \mathrm{~mm}$. Overlapping slices were recorded of the rabbits from head to toe during the measurement. For the segmentation process, masks were made for the loin muscle and the hind legs, and registered to the CT images for each animal.

\section{Animal Models}

To estimate genetic parameters, REML and BLUP methods were used for the LM and HL in a twotrait animal model. The pedigree file consisted 2758 individuals. PEST software (Neustadt, Germany) (Groeneveld, 1990) was used for data coding and the variance components were estimated with VCE 6 (Groeneveld et al., 2008). The structure of the applied model is summarized in Tab. I.

\section{Selection Index}

After the calculation of the genetic parameters, a two-trait desired gain selection index was created by MIX software (Nath et al., 2002).

The desired gain was calculated by the method of Yamada et al. (1975), as follows:

$\mathrm{Q}$ is the $\mathrm{m} \times 1$ vector of the desired gain of the traits included:

$\mathrm{Q}=(\mathrm{Q} 1, \mathrm{Q} 2)$.

In order to attain desired gains, selection was made on the basis of the index.

$\mathrm{I}=\mathrm{b} \mathrm{O}^{\prime} \mathrm{X}$

where $\mathrm{X}=\mathrm{n} \times 1$ vector of LMV and HLV, $\mathrm{b}=\mathrm{n} \times 1$ vector of weighting coefficients.

The expected genetic gain per generation of the $\mathrm{i}^{\text {th }}$ trait was computed as:

$\Delta G_{i}=\frac{i_{l} \operatorname{Cov}\left(G_{i}, I\right)}{\sigma_{l}}$,

where $\mathrm{i}_{1}=$ selection intensity; $\sigma_{\mathrm{I}}=(\mathrm{b}$ 'Pb) $1 / 2$ (standard deviation of the index), and $/ \mathrm{P}=\mathrm{n} \times \mathrm{n}$ matrix of phenotypic variance-covariance between the elements of X. Cov. $\left(G_{i}, I\right)=\left(G^{\prime} b\right)$ (covariance of the breeding value of trait and the index).

The final index was Z-transformed to get 100 as mean of the index and 20 for standard deviation.

Index $=6.3 \times \mathrm{LMV}+4.13 \times \mathrm{TMV}$.

Number of generations required to attain the goal (t) were calculated as: $t=\sigma_{\mathrm{I}} / \mathrm{i}_{\mathrm{I}}=(\mathrm{b}, \mathrm{Pb})^{1 / 2} / \mathrm{i}_{\mathrm{I}}$.

I: The applied animal model

\begin{tabular}{|c|c|c|c|c|}
\hline \multirow{2}{*}{ Effect } & \multirow{2}{*}{ Type } & \multirow{2}{*}{ Levels } & \multicolumn{2}{|c|}{ Trait } \\
\hline & & & LMV & HLV \\
\hline Sex & $\mathrm{F}$ & 2 & $\mathrm{X}$ & X \\
\hline Year_month & $\mathrm{F}$ & 17 & $\mathrm{X}$ & $X$ \\
\hline Pixel & $\mathrm{F}$ & 1 & $\mathrm{X}$ & $X$ \\
\hline CT_weight & $\mathrm{C}$ & 1 & $\mathrm{X}$ & $\mathrm{X}$ \\
\hline A & A & 2758 & $\mathrm{X}$ & $\mathrm{X}$ \\
\hline
\end{tabular}

Where: LMV: Loin muscle volume; HLV: hind leg muscle volume; Sex: sex of growing rabbits; Year_month: year and month of kindling; Pixel: density range of the muscle tissue; CT_weight: bodyweight at the CT meaurement; A: additive genetic effect 
II: Descriptive statistics of the traits

\begin{tabular}{lccccc}
\multicolumn{1}{c}{ Trait } & N & Minimum & Maximum & Mean & SD \\
\hline LMV $\left(\mathrm{cm}^{3}\right)$ & 312 & 98.58 & 232.68 & 157.11 & 23.99 \\
HLV $\left(\mathrm{cm}^{3}\right)$ & 312 & 278.91 & 478.48 & 374.33 & 39.43 \\
CT_weight (g) & 312 & 2350 & 3620 & 2957 & 212.55 \\
\hline
\end{tabular}

Where: LMV is the volume of the loin muscle; HLV is the volume of the hind legs; CT_weight: bodyweight at the CT measurement

III: Heritabilities, genetic correlations and standard errors of the measured traits

\begin{tabular}{lcc}
\hline \multicolumn{1}{c}{ Traits } & $\mathrm{h}^{2}$ & rg LMV-HLV \\
\hline LMV & 0.4 & $0.68 \pm 0.08$ \\
HLV & 0.42 & \\
\hline
\end{tabular}

\section{RESULTS}

The mean values of HLV are in accordance with the results for thigh muscle volume (TMV) of the Pannon white rabbit breed (Ács et al., 2018), however, the results are somewhat higher due to the breed differences and the slight changes in the CT segmentation method.

The genetic correlations, estimated heritabilities are summarized in Tab. III.

Correlation coefficients between the examined traits and the selection index are presented in Fig. 1 and Fig. 2.

After the $\mathrm{Z}$ transformation, the means of the estimated breeding values for the examined traits were somewhat higher (4.9 for LMV and 4.9 for HLV) than the index score (4.6). A favorable genetic correlation was found between LMV and HLV (0.68) and the correlation coefficients of both the LMV and the HLV were strongly positive, therefore it is advisable to link them with a selection index.

\section{DISCUSSION}

LMV showed relatively high heritability $\left(\mathrm{h}^{2}=0.4\right)$, in contrast with Lenoir and Morien, (2016), where CT evaluation was substituted with ultrasound device due to economic reasons. They measured the surface of the $m$. longissimus dorsi, and observed a moderate heritability $\left(h^{2}=0.2\right)$. In the Pannon White rabbit breed, previous selection criteria (L-value) was expressed in $\mathrm{cm}^{2}$ and the heritability of the trait was $h^{2}=0.33$ (Matics et al., 2014), thus adding LMV to the breeding goal may result a more accurate selection decision.

For the hind legs, the heritability of the muscle volume is also high $\left(\mathrm{h}^{2}=0.4\right)$. Heritability estimations were reported previously for thigh muscle volume in the Pannon large and the Pannon white breed, but these results were moderate $\left(h^{2}=0.21-0.25\right)$ (Gyovai et al., 2012).

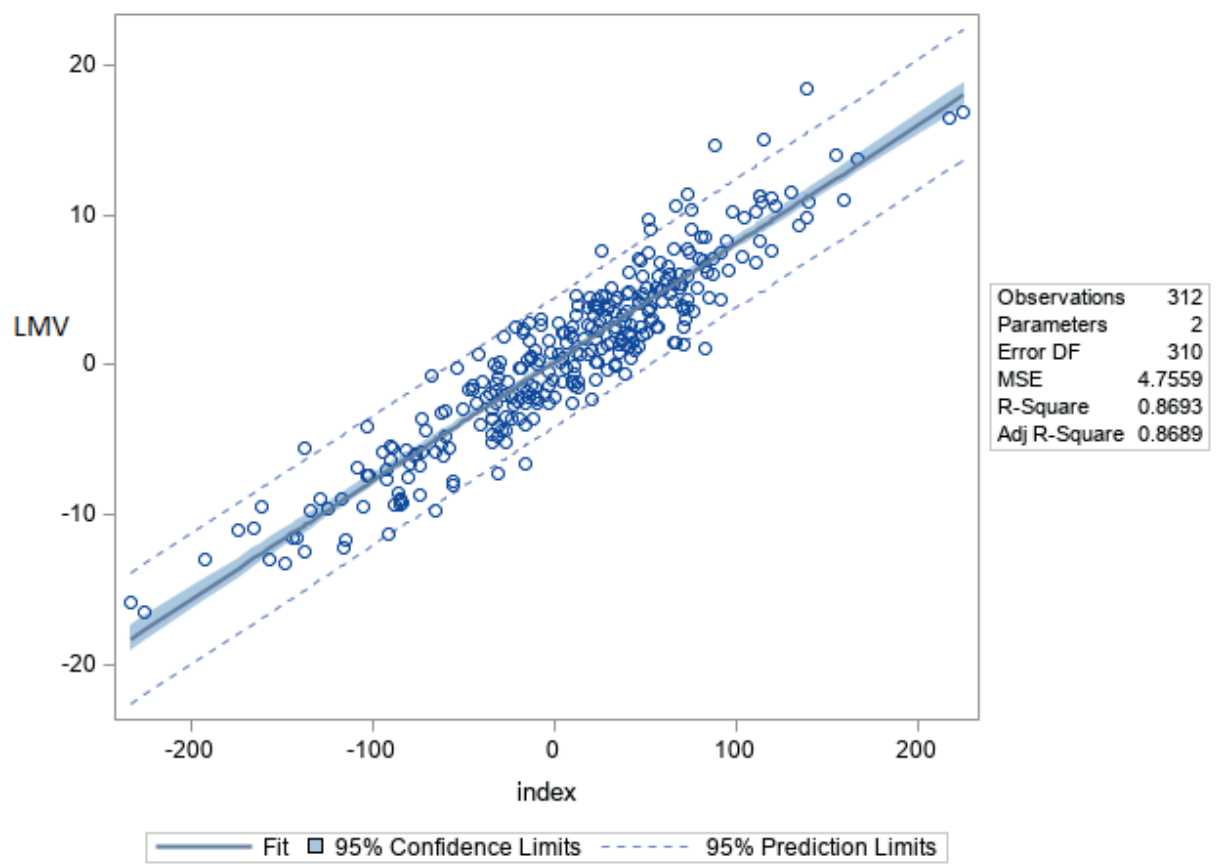

1: Correlation coefficient of the selection index and the loin muscle volume 


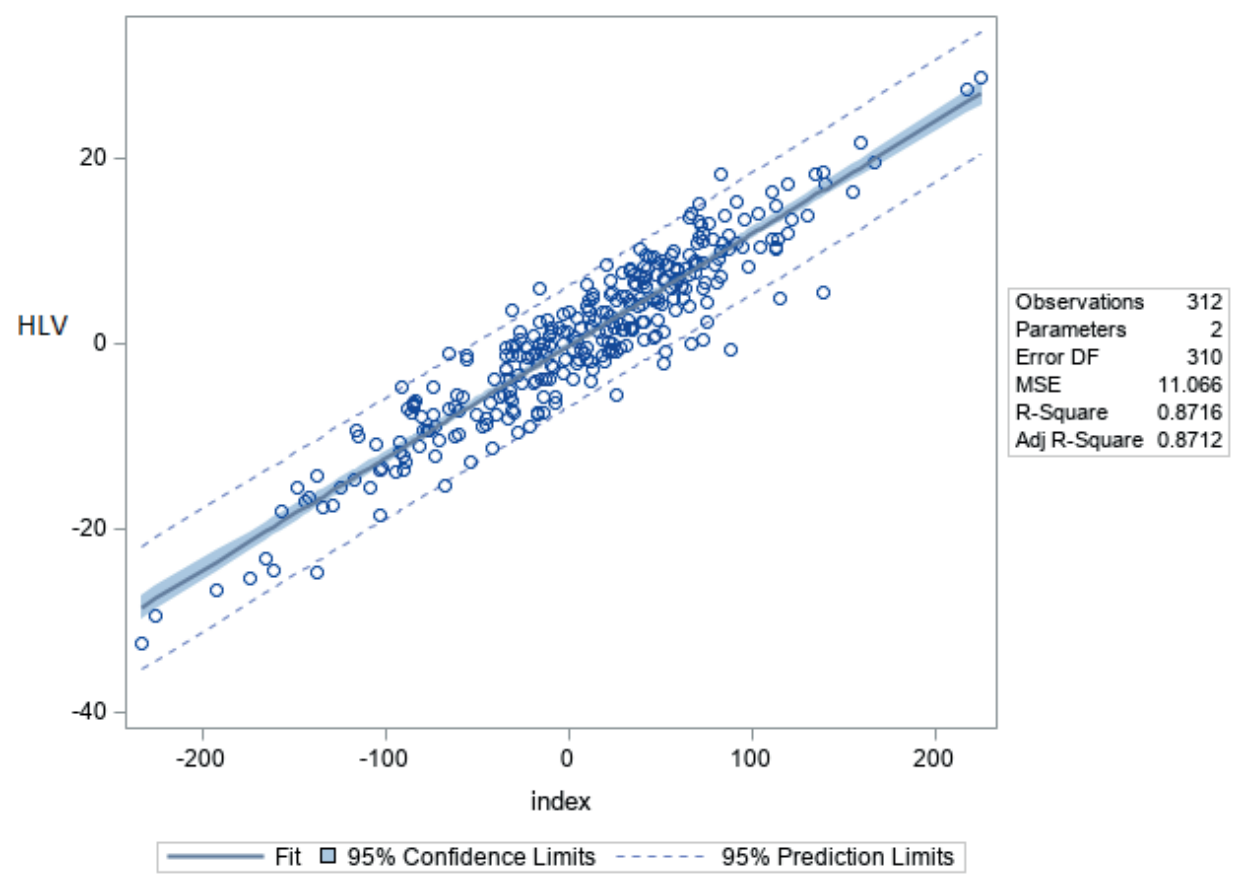

2: Correlation coefficient of the selection index and the muscle volume of the hind legs

Matics et al., (2014) reported high genetic correlations between thigh muscle volume and the dressing out percentage (0.45-0.47) earlier. The number of generations required to improve the traits with one additive genetic standard deviation was 11.9, which can be achieved in approximately 5 years of selective breeding.

\section{CONCLUSION}

Applying selection index method is reasonable in the Pannon large breed, especially for carcass traits. As a paternal crossing partner, the amount of the valuable meat parts has to be improved, thus more profit can be obtained for the slaughterhouse. If traits are difficult to determine from an economic point of view the implementation of "desired gains" can be a good alternative to create a new breeding goal.

\section{Acknowledgements}

The research was supported by János Bolyai Research Scholarship BO/00871/19 of the Hungarian Academy of Sciences. The publication was co-financed by the European Union and the European Social Fund EFOP-3.6.1-16-2016-00007.

\section{REFERENCES}

ÁCS, V., SZENDRŐ, K., GARREAU, H., DONKÓ, T., MATICS, Z. and NAGY, I. 2018. Application possibilities of selection indices in the Pannon white rabbit's breeding programme. Italian Journal of Animal Sci., 17(4): 884-889.

DONKÓ, T., CZAKÓ, B., KOVACS, G., PETNEHAZY, O., KASZA, R., SZENDRŐ, Z., GARAMVÖLGYI, R. and MATICS, Z. 2016. Total body fat content determination by means of computed tomography (CT) in rabbits. In: Proc. $11^{\text {th }}$ World Rabbit Congress. 2016 June, Qingdao, China.

GJERLAUG-ENGER, E., KONGSRO, J., ØDEGARD, J., AASS, L. and VANGEN, O. 2012. Genetic parameters between slaughter pig effi ciency and growth rate of different body tissues estimated by computed tomography in live boars of Landrace and Duroc. Animal., 6(1): 9-18.

GROENEVELD, E. 1990. PEST User's manual. Institute of animal husbandry and animal behavior. Neustadt: Federal Research Centre.

GROENEVELD, E., KOVAC, M. and MIELENZ, N. 2008. VCE User's guide and reference manual. Version 6.0. Neustadt, Germany: Institute of Farm Genetics. 
GYOVAI, P., NAGY, I., GERENCSER, Z., MATICS, Z., RADNAI, I., DONKO, T., BOKOR, A., FARKAS, J. and SZENDRO, Z. 2012. Genetic parameters for litter weight, average daily gain and thigh muscle volume measured by in vivo computer tomography technique in Pannon White rabbits. Livestock Sci., 144: 119-123.

HAZEL, L. N. 1943. The genetic basis for constructing selection indexes. Genetics, 28(6): 476-490.

JONES, H. E., LEWIS, R. M., YOUNG, M. J. and SIMM, G. 2004. Genetic parameters for carcass composition and muscularity in sheep measured by X-ray computer tomography, ultrasound and dissection. Livest. Prod. Sci., 90(2-3): 167-179.

KHALIL, M. M. and AL-SAEF, A. M. 2008. Methods, criteria, techniques and genetic responses for rabbit selection: A review. In: $9^{\text {th }}$ World Rabbit Congress. Verona, Italy. Invited paper, Genetics Session, pp. 1-22.

LENOIR, G. and MORIEN, F. 2016. Estimation of genetic parameters for carcass traits evaluated by in vivo real-time ultrasonography in meat rabbit breeding. In: Proceedings of the $11^{\text {th }}$ World Rabbit Congress. Qingdao, China, 15-18 June, 2016, World Rabbit Science Association.

MATICS, Z., NAGY, I., GERENCSER, Z., RADNAI, I., GYOVAI, P., DONKO, T., DALLE ZOTTE, A., CURIK, I. and SZENDRO, Z. 2014. Pannon breeding program in rabbit at Kaposvar university. World Rabbit Sci., 22: 287-300.

NATH, M., SINGH, B. P., SAXENA, V. K., DEV ROY, A. K. and SINGH, R. V. 2002. MIX: A software for construction of multi-trait selection index. In: $7^{\text {th }}$ World's Congress on Genetics Applied to Livestock Production. August 19-23, 2002, Montpellier, France.

PESEK, J. and BAKER, R. J. 1969. Desired improvement in relation to selection indices. Can. J. Plant Sci., 49: 803-804.

PILES, M., BLASCO, A. and PLA, M. 2000. The effect of selection for growth rate on carcass composition and meat characteristics of rabbits. Meat Sci., 54(4): 347-355.

SZENDRŐ, Z., HORN, P, KÖVÉR, G., BERÉNYI, E., RADNAI, I. and BÍRÓNÉ NÉMETH, E. 1992. In vivo measurement of the carcass traits of meat type rabbits by X-ray computerised tomography. J. Appl. Rabbit. Res., 15: 799-809.

YAMADA, Y., YOKOUCHI, K. and NISHIDA, A. 1975. Selection index when genetic gains of individual traits are of primary concern. Japanese J. Genet., 50(1): 33-41.

Contact information

Virág Ács: acs.virag@ke.hu

István Nagy: nagy.istvan@ke.hu

Tamás Donkó: donko.tamas@sic.medicopus.hu 